$\begin{gathered}\text { Науковий вісник Нлту України } \\ \text { Scientific Bulletin of UNFU } \\ \text { http://nv.nltu.edu.ua } \\ \text { https://doi.org/10.15421/40280321 } \\ \text { Article received 23.03.2018 p. } \\ \text { Article accepted 26.04.2018 p. } \\ \text { Удк 621.311.32 }\end{gathered}$
$\begin{aligned} & \text { M. F. Zayats } \\ & \text { ISSN 2519-2477 (online) }\end{aligned}$
marzayf@gmail.com

М. П. Кузик, М. Ф. Заяць

Національний університет "Львівська політехніка", м. Львів, Україна

\title{
КІНЕТИЧНІ ХАРАКТЕРИСТИКИ СУШІННЯ КОТЛІВ ТП-10 ЗА ДОПОМОГОЮ ТЕПЛОТИ ЖИВИЛЬНОЇ ВОДИ
}

\begin{abstract}
Спалювання непроектного вугілля на теплових електростанціях неминуче призводить до забруднення зовнішніх поверхонь нагріву котла і як наслідок - до погіршення техніко-економічних показників роботи пиловугільного котла. Аналізуючи літературні джерела та досвід експлуатації електростанцій, визначено основні чинники, які зумовлюють перебіг корозійних процесів на зовнішніх поверхнях нагрівання котлів під час спалювання різних видів палива та вплив на них режимів роботи котлів. До основних чинників, що зумовлюють процеси корозії на зовнішніх поверхнях нагрівання котлів, які розміщені в резерві, належать: вид і властивості палива, яке спалюється перед виведенням котлів у резерв - хімічний склад і властивості відкладень на поверхнях нагрівання, відносна вологість і температура повітря, що оточує поверхні нагрівання, проведені заходи для зниження вмісту сірки у відкладеннях на поверхнях нагрівання перед виведенням їх у резерв. Практикою експлуатації встановлено, що ретельно очистити поверхні від відкладень можливо тільки за допомогою водяного обмивання. Після обмивання потрібно провести якісне сушіння всіх зволожених поверхонь котла, щоб мінімізувати процеси низькотемпературної корозії. Викладено результати дослідження режимів малозатратної та ефективної процедури сушіння шляхом подачі в пароводяний тракт котла живильної води зі загальностанційного трубопроводу.
\end{abstract}

Ключові слова: паливо; вологість повітря; температура повітря; обмивання котлів; винесення вологи.

Вступ. Генерація електроенергії на теплових електростанціях, де використовують пиловугільні котли, ще тривалий час буде основним способом отримання електроенергії. Ефективність роботи котлів значною мірою залежить від стану їх теплосприймальних поверхонь. Це потребує періодичної очищення цих поверхонь. Водяне обмивання $є$ одним $з$ найефективніших способів очищення. Проте після його проведення необхідне ретельне сушіння поверхонь котла (Hut et al., 2008, 2009).

Одним 3 найраціональніших методів сушіння, який може бути реалізований на котлах ТЕС 3 поперечними зв'язками, зокрема на котлах ТП-10, полягає в подачі у пароводяний тракт котла живильної води зі загальностанційного трубопроводу (Brykailo \& Mysak, 2008; Yanko \& Mysak, 2004; Mysak, Tymofieiev \& Zayats, 2009), що призводить до нагрівання повітря в конвективній шахті. Внаслідок спеціально проведених експериментів із обмивання і сушіння поверхонь нагріву згідно з наведеним вище методом визначено низку параметрів процедури сушіння (Kuzyk, Brykailo \& Mysak, 2012).

У цій роботі проаналізовано кінетичні характеристики процесу сушіння поверхонь нагрівання котлів ТП10 після їх водяного обмивання для встановлення певних закономірностей, які можна було б використати для оптимізації процедури сушіння.
Матеріали та методи дослідження. Для унаочнення проведеного аналізу наводимо отриману (обмивання № 2 із серії 5 дослідів) за описаною в (Kuzyk, Brykailo \& Mysak, 2012) технологією, криву (рис. 1) часової залежності абсолютної вологості $\rho=\rho(\tau)$ повітря в нижній частині конвективної шахти (підбункернику) під час роботи димотяга у процесі сушіння. Ця крива найбільш характерна для тих дослідів, що здійснювали в закритому напрямному апараті димотяга. Стан напрямного апарату (відкритий, закритий) зумовлює певні особливості ходу кривих $\rho=\rho(\tau)$ за їх загальної подібності (Yanko \& Mysak, 2004).

Суцільна лінія на рис. 1 відповідає апроксимації отриманих експериментальних значень вологості повітря за допомогою полінома виду

$$
\begin{aligned}
\rho(\tau)= & 6,9571+2,66333 \tau-0,11017 \tau^{2}+0,00153 \tau^{3}- \\
& -5,72716 \cdot 10^{-6} \tau^{4}-1,56037 \cdot 10^{-8} \tau^{5} .
\end{aligned}
$$

Аналіз ходу кривої на рис. 1 (обмивання № 2) та аналогічних кривих інших обмивань дає змогу стверджувати, що найбільш подібними для них є кінцева фаза сушіння після проходження максимуму вологості $\rho_{\text {мах }}$ (задній фронт кривої). Останній ще $є$ цікавий тим, що за наявності певних закономірностей, виникає можливість прогнозування тривалості кінцевої фази сушіння, а це пов'язано з оптимізацією енергетичних затрат.

\section{Інформація про авторів:}

Кузик Мирон Петрович, канд. фіз.-мат. наук, доцент, кафедра теплоенергетики, теплових і атомних електричних станцій. Email: kuzyk.lp@gmail.com

Заяць Марія Федорівна, ст. викладач кафедри теплоенергетики, теплових і атомних електричних станцій. Email: marzayf@gmail.com

Цитування за ДСтУ: Кузик М. П., Заяць М. Ф. Кінетичні характеристики сушіння котлів ТП-10 за допомогою теплоти живильної води. Науковий вісник НЛту України. 2018, т. 28, № 3. С. 101-104.

Citation APA: Kuzyk, M. P., \& Zayats, M. F. (2018). Kinetic Characteristics of Drying of Boilers TP-10 With Using Feedwater Heat. Scientific Bulletin of UNFU, 28(3), 101-104. https://doi.org/10.15421/40280321 


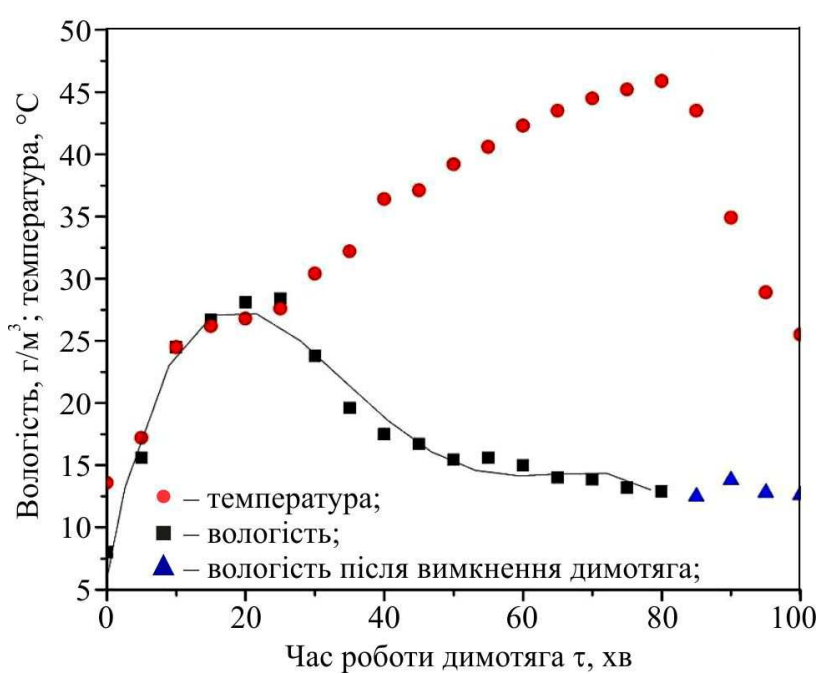

Рис. 1. Залежність вологості та температури повітря у підбункернику котла ТП-10 під час роботи димотяга

Процес порівняння і знаходження закономірностей ходу кінцевої фази для різних обмивань показав, що необхідно виключити такий фактор, як абсолютна вологість фону $\rho_{\phi}$ (повітря котельного приміщення як сушильного агента), оскільки для різних обмивань вона різна. Отже, беремо до уваги величину $\rho-\rho_{\phi}$. Оскільки максимуми $\rho_{\text {мах }}$ кривих $\rho=\rho(\tau)$ для різних обмивань мають різну амплітуду, то $\epsilon$ сенс нормувати змінні значення $\rho$ відносно $\rho_{\text {мах }}$, тобто оперувати безрозмірними величинами $\rho / \rho_{\text {мax }}$, а ще точніше $\left(\rho-\rho_{\phi}\right) /\left(\rho_{\text {мax }}-\rho_{\phi}\right)$. Окрім цього, відлік часу кінцевої фази необхідно починати 3 моменту проходження згаданого максимуму. На рис. 2 спільно для другого та четвертого обмивань наведено хід нормованих вказаним чином значень вологості як функції часу, нульовий відлік якого збігається з моментом проходження $\rho_{\text {мах }}$. Апроксимацію ходу об'єднаних експериментальних значень проведено за допомогою Програми Origin 7.5. Найкращу апроксимацію забезпечує такий вираз:

$$
\left(\rho-\rho_{\phi}\right) /\left(\rho_{\text {мак }}-\rho_{\phi}\right)=0,0101+0,990 \times e^{-\tau / 37,3},
$$

де $\tau$ - час після проходження максимуму вологості, хв.

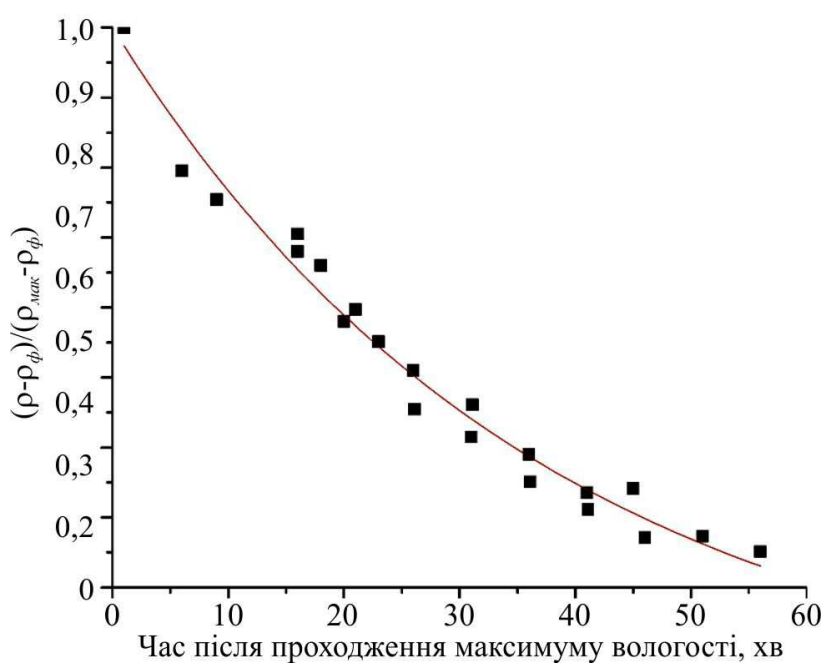

Рис. 2. Нормований спад вологості спільний для 2 і 4 обмивань (напрямний апарат димотяга закритий)

Формулу (2) розглядаємо як математичну модель кінцевої фази процесу сушіння. Використовуючи цю формулу, можна оцінити час сушіння, точніше час роботи димотяга після проходження максимуму вологості, за різних заданих величин кінцевого значення абсо- лютної вологості в газоході котла (у підбункернику), а отже, і в котлі загалом.

При цьому швидкість подачі живильної води під час термічного сушіння поверхонь нагріву конвективної шахти котла ТП-10 повинна знаходитись в діапазоні $2 \div 3$ л/с, напрямний апарат димотяга в момент подачі живильної води повинен бути повністю закритим. При включеному димотягу його напрямний апарат повинен бути відкритий на $10 \div 15 \%$.

Щодо сушіння котла за відкритого напрямного апарату димотяга, то тут формули типу (2), загальної для різних обмивань, не вдалось знайти. Самотяга, яка виникає в разі відкритого напрямного апарату, є явищем достатньо невпорядкованим, істотно залежить від різниць температур ззовні, в котельному приміщенні, зольні тощо.

Результати дослідження. Певний інтерес має кінетика виносу вологи 3 котла за час роботи димотяга. Для iii дослідження врахуємо, що площа під кривими $\rho=\rho(\tau)$ на рис. 1 пропорційна масі вологи $M$, яка пройшла через газопровід котла за проміжок часу від $\tau_{1}=0$ до $\tau_{2}$, який дорівнює тривалості роботи димотяга.

Використаємо наведену вище апроксимаційну формулу (1), яка описує хід кривої $\rho=\rho(\tau)$ для другого обмивання і сушіння, що здійснювалось за закритого напрямного апарату димотяга. Тоді маса вологи М, яка покидає котел в проміжку часу від $\tau_{1}$ до $\tau_{2}$, дорівнює

$$
\begin{aligned}
& M=V \int_{\tau_{1}}^{\tau_{2}} \rho(\tau) d \tau=3240 \int_{\tau_{1}}^{\tau_{2}}\left(6,9571+2,66333 \tau-0,11012 \tau^{2}+\right. \\
& \left.+0,00153 \tau^{3}-5,72716 \times 10^{-6} \tau^{4}-1,56037 \times 10^{-8} \times \tau^{5}\right) d \tau,
\end{aligned}
$$

де $V$ - об'єм повітря, який проходить газоходом котла за одиницю часу і який дорівнює в наших експериментах $3240 \mathrm{~m}^{3} /$ Хв.

Для визначення (встановлення) кінетики процесу видалення вологи 3 котла в процесі роботи димотяга обчислено згідно з виразом (2) значення М для $\tau_{2}=10 ; 20$; $30 ; 40 ; 50 ; 60 ; 70$ і 80 хв $\left(\tau_{1}=0\right)$.

Чисту (без вологи сушильного агента на вході) масу вологи $\mathrm{M}_{\mathrm{B}}$, яка виносилась $з$ поверхонь котла, визначено як

$$
M_{B}=M-M_{\Phi}=M-\left(\tau_{2}-\tau_{1}\right) \cdot \rho_{\phi} \cdot \mathrm{V} .
$$

Залежність процесу виносу вологи від часу роботи для другого обмивання наведено на рис. 3.

Апроксимаційна формула цього графіка має такий вигляд:

$$
M_{6}=A_{2}+\left(A_{1}-A_{2}\right) /[1+\exp ((\tau-B) / C)],
$$

де: $A_{1}=-950$ кг; $A_{2}=3230$ кг; $B=22,3$ хв; $C=17,4$ хв.

Застосування формули (5) для опису кінетики процесу сушіння котла дає змогу оцінити граничну величину вологи $M_{\text {в.гран }}$, що міститься на стінках котла після обмивання. Якщо час роботи димотяга $\tau \rightarrow \infty$, то 3 (5) випливає, що для другого обмивання $M_{\text {в.гран }}=A_{2}=3230 \kappa 2$.

Таким чином, на прикладі другого обмивання (за закритого напрямного апарату димотяга) визначено масу води, яка покинула котел ТП-10 у процесі сушіння, i яка становить приблизно 3200 кг. Отже, після водяного обмивання котла на поверхнях, переважно конвективної шахти, залишається значна, вимірювана в тоннах, кількість вологи, випаровування якої природним шляхом є достатньо тривалим процесом. Ця волога здатна 
істотно пришвидшувати процеси атмосферної корозії зовнішніх поверхонь нагрівання.

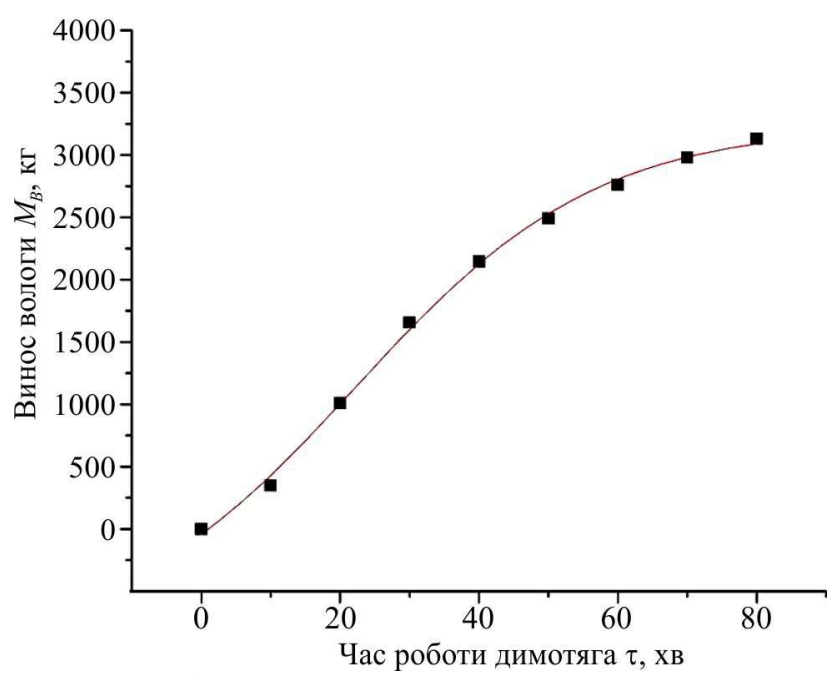

Рис. 3. Залежність процесу виносу вологи від часу роботи димотяга

\section{Висновки}

1. Кінцева фаза процедури сушіння в координатах "вологість сушильного агента на виході 3 котла - час роботи димотяга" описується, в разі закритого напрямного апарату димотяга під час подачі живильної води, експоненціальною залежністю.

2. Ця залежність дає змогу прогнозувати тривалість роботи димотяга залежно від вологості повітря в котельному приміщенні $\rho_{\phi}$, максимуму вологості в нижній частині котла $\rho_{\text {мак }}$ під час роботи димотяга. В такий спосіб можна оптимізувати процедуру сушіння поверхонь нагріву котла з огляду на затрати енергії.

3. Визначено кількість вологи, яка виноситься під час термічного сушіння котла ТП-10 після його обмивання i становить приблизно 3200 кг.
4. Під час простоювання котлів у резерві чи консервації метал поверхонь нагрівання перебуває в близькому до нейтрального середовища, де температура точки роси залежить від відносної вологості і температури навколишнього середовища, яка в реальних кліматичних та експлуатаційних умовах становить $15-20{ }^{\circ} \mathrm{C}$ зі запасом на непередбачені обставини, тобто в значно нижчому діапазоні.

\section{Перелік використаних джерел}

Brykailo, R. V., \& Mysak, Y. S. (2008). Kotelna ustanovka pat. 85517 Ukraina: MPK F22B33/00, F23C 9/00, F23L 15/00; zaiavnyky i patentovlasnyky Dobrotvirska TES VAT "ZAKhIDENERHO", Natsionalnyi universytet "Lvivska politekhnika". № a 2007 03316; zaiavl. 27.03.2007; opubl. 10.10.2008. Biul. № 19. 4 p.

Hut, P. O., Mysak, Y. S., Zayats, M. F., Tymofieiev, I. L., \& Mysak I. V. (2009). Sposib zakhystu metalu nyzkotemperaturnykh poverkhon nahrivu kotla vid korozii pat. 40591 Ukraina: MPK F23J 15/00, B01D 53/26, B01D 53/60; zaiavnyky i patentovlasnyky VAT "LvivORHRES", Natsionalnyi universytet "Lvivska politekhnika". № a 2007 10185; zaiavl. 12.09.2007; opubl. 27.04.2009. Biul. № 8. 4 p.

Hut, P. O., Mysak, Y. S., Zayats, M. F., Tymofieiev, I. L., \& Mysak, I. V. (2008). Sposib zakhystu metalu nyzkotemperaturnykh poverkhon nahrivu kotla vid sirchanokysloi korozii pat. 84379 Ukraina: MPK S23F11/10, F22V 37/00, F23J 15/00; zaiavnyky i patentovlasnyky VAT "LvivORHRES", Natsionalnyi universytet "Lvivska politekhnika". № a 2007 10639; zaiavl. 26.09.2007; opubl. 10.10.2008. Biul. № 19. 4 p.

Kuzyk, M. P., Brykailo, R. V., \& Mysak, Y. S. (2012). Sushinnia zovnishnikh poverkhon nahrivannia kotliv TP-10 za dopomohoiu zhyvylnoi vody. Skhidno-Ievropeiskyi zhurnal peredovykh tekhnolohii, 2/8(56), 12-17.

Mysak, Y. S., Tymofieiev, I. L., \& Zayats, M. F. (2009). Vodopidhotovka, vodno-khimichnyi rezhym ta konservatsiia teploenerhetychnoho ustatkuvannia elektrostantsii. Lviv: NVF " Ukrainski tekhnolohii". 168 p.

Yanko, P. I., \& Mysak, Y. S. (2004). Rezhymy ekspluatatsii enerhetychnykh kotliv. Lviv: PVF "Ukrainski tekhnolohii". 272 p.

М. П. Кузык, М. Ф. Заяч

Национальный университет "Львовская политехника", г. Львов, Украина

\title{
КИНЕТИЧЕСКИЕ ХАРАКТЕРИСТИКИ СУШКИ КОТЛОВ ТП-10
} С ПОМОЩЬЮ ТЕПЛОТЫ ПИТАТЕЛЬНОЙ ВОДЫ

\begin{abstract}
Сжигание угля на тепловых электростанциях неминуемо приводит к загрязнению тепловоспринимающих поверхностей нагрева котла и как следствие - к ухудшению технико-экономических показателей работы пылеугольного котла. Анализируя литературные источники и опыт эксплуатации электростанций, определены основные факторы, которые способствуют прохождению коррозионных процессов на внешних поверхностях нагрева котлов при сжигании различных видов топлива и влияние на них режимов работы котлов. Установлено, что тщательно очистить поверхности от загрязняющих отложений возможно лишь с помощью водяного обмывания. После обмывания необходимо провести качественную сушку всех увлажненных поверхностей котла для минимизации процессов низкотемпературной коррозии. Изложены результаты исследования режимов малозатратной и эффективной технологии сушки путем подачи в пароводяной тракт котла питательной воды с общестанционного трубопровода. Данная зависимость позволяет прогнозировать продолжительность работы дымососа в зависимости от влажности воздуха в котельном помещении $\rho_{\phi}$, максимума влажности в нижней части котла $\rho_{\text {мак }}$ во время работы дымососа. Таким образом можно оптимизировать процедуру сушки поверхностей нагрева котла учитывая затраты энергии. Определено количество влаги, которое выносится при термической сушке котла ТП-10 после его обмывания, и составляет примерно 3,2 т.
\end{abstract}

Ключевые слова: топливо; влажность воздуха; температура воздуха; обмывание котлов; вынесения влаги.

M. P. Kuzyk, M. F. Zayats

Lviv Polytechnic National University, Lviv, Ukraine

\section{KINETIC CHARACTERISTICS OF DRYING OF BOILERS TI-10 WITH USING FEEDWATER HEAT}

Combustion of coal in thermal power plants will inevitably result in contamination of the heat-receiving surfaces of the boiler heating and, as a consequence, deterioration of the technical and economic performance of the pulverized coal boiler. Practice of operation has defined that it is possible to thoroughly clean the surfaces of polluting deposits only with the help of water washing. After washing, it is necessary to carry out a high-quality drying of all humidified surfaces of the boiler to minimize the processes of low-temperature corrosion. The results of studies of low-cost and efficient drying technologies by supplying feed water from the 
general-purpose pipeline to the steam-water tract of the boiler are described in this paper. One of the most rational drying methods that can be implemented on TPP boilers with transverse bonds, in particular on TП-10 boilers, is to feed the boiler feed water from the general-purpose pipeline to the steam-water path, which leads to heating the air in a convection mine. Feed rate of feed water was no more than $3 \mathrm{l} / \mathrm{s}$. The temperature of the heating of the top of the mine reached $70^{\circ} \mathrm{C}$. Warm air moves through the gas circuit, heats up the external surfaces of the heater and the moisture left over there, which is removed outside the boiler installation by the inclusion of smoke and partly due to the smoke chute self-movement. In the course of the research we obtained the time dependence of air humidity at the outlet of the convection shaft during the operation of the smoke outlet, which can be considered as the dynamic dependence of the drying process. We also obtained a formula that describes the dynamics of the final phase of the drying process. Using this formula we can estimate drying time, more precisely the operating time of the smoke exhaust after the maximum moisture content at various predetermined values of the final value of absolute humidity in the gas boiler (in the hopper) and, consequently, in the boiler as a whole. Having analysed the experimental data, we obtained the temporal dependence of the process of removing moisture from the boiler during the operation of the smoke exhaust. This allowed us to estimate the limit value of moisture contained on the walls of the ТП-10 boiler after washing, which is approximately $3.2 \mathrm{t}$. This dependence allows predicting the duration of the operation of the smoke generator, depending on the humidity of the air in the boiler room and the maximum moisture content in the bottom of the boiler during the operation of the smoke outlet. Thus, it is possible to optimize the procedure of drying the heating surfaces of the boiler in view of energy costs.

Keywords: fuel; air humidity; air temperature; washing of boilers; removal of moisture. 